\title{
Market Regulatory in Surabaya 1914 - 1930
}

\author{
Thomas Nugroho Aji ${ }^{1}$, Sri Mastuti Purwaningsih ${ }^{2}$, Arief Sudrajat ${ }^{3}$ \\ \{thomasnugroho@unesa.ac.id ${ }^{1}$, srimastuti@unesa.ac.id ${ }^{2}$, ariefsudrajat@unesa.ac.id $^{3}$ \} \\ ${ }^{1,2}$ History Education Departement, Sociology Departement, Indonesia \\ ${ }^{3}$ Universitas Negeri Surabaya, Indonesia
}

\begin{abstract}
Market management in Dutch East Indies was established by the policy of Governor-General of the Dutch East Indies 1913, the Minister of Colonies Idenburg letter, dated on February 5, 1914, as well as the directives of the Council of the Indies, dated on 4 April 1914. Based on the proposal of the Dutch East Indies government was issued on 06 September 1914 about the Decentralisatie Maarktwezen or decentralized market business. Surabaya was designated as Gemeente (autonomous city) through Staatsblad No. 149 of 1906. As a consequence of the establishment of Surabaya as an autonomous region (Gemeente), several obligations which were initially carried out by the central government were left entirely to Surabaya. One of the matters handed over by management was market management. Market management (bedrijf maarkt) was carried out through the Gemeente about Market Service formed in 1915 including in terms of managing the market environment itself by the Surabaya city government. The purpose of market management was to meet the needs of society as well as structuring locations for the purpose of an environmental regulation market town. The Issues to be observed is Surabaya Gemeente activity in the market management of the city and its environmental management activities.
\end{abstract}

Keywords: Market, Gemeente, Surabaya, Urban Environment Management

\section{Introduction}

The history of market regulation in Surabaya began when the idea of implementing decentralization began to apply to the Dutch East Indies government for certain regions or cities. One city that is given the authority to regulate its own area was Surabaya.

The application of the decentralization aspect was stated in the Decentralisatie Wet [1] on 23 July 1903 and promulgated in the Staatsblad van Nederlandsch-Indië 1903 No. 329. This is a new history in the administration of the colonial government in the Dutch East Indies. Although the beginning of the implementation of this policy was still deconcentrated due to the fact that it was still not entirely the central government relinquished control of resident residents and assistants in regulating government in the region. 
One of the elements regulated in the implementation of the Surabaya City government autonomy policy is the problem of market structuring. The existence of the market in Surabaya requires arrangements, especially those related to the regulation of social institutions, which certainly bring financial benefits to the cash of the Surabaya Municipal Council after the implementation of autonomy in the interests of meeting the needs of the city independently.

\section{Research Methodology}

In this study using historical approaches, namely heuristics, criticism, interpretation, and historiography. In the heuristic aspect, researchers use primary and secondary data in the form of historical documents, journals, or written sources related to the market in Surabaya. Criticism in the form of sorting out data that is feasible is used to support this research so that not all data can be used. Data interpretation in the form of interpretation of the facts that have been obtained and linking relationships between facts so as to produce historical facts that are in accordance with the truth. The next step is to conduct historiography activities, namely activities to compile historical facts either chronologically or diachronic.

The form of this study is descriptive qualitative with the aim of uncovering the facts and description of the existence of markets and market arrangements during the Dutch East Indies after the establishment of Surabaya as an autonomous township.

\section{Results and Discussions}

\subsection{Surabaya Kotapraja Market 1914}

Since the 19th century, Surabaya has become one of the most influential port cities and has become a shelter for various commodities imported from the interior of Java to the outer islands of Java so that trade offices and warehouses for the collection of these commodities emerge. Surabaya eventually developed rapidly into a city of modern commerce at that time and affected the economic conditions of the city especially after it was designated as one of the cities that had autonomy in the administration and administration of the city.

As one of the fastest-growing trading cities, the market presence is important in the sale and purchase of commodity goods. The emergence of the market in Surabaya Municipality was also influenced by the increase in the population of the city and the emergence of new settlements [2]. Entering the 20th century, the population growth of the Surabaya Municipality gave rise to several settlements based on ethnicity and at the same time gave rise to distinctions such as the example of the Arab villages that gave rise to craft centers and typical markets of goods from the Arabian Peninsula. The Chinese village raised the center of the grocery market (a market that provided daily necessities such as brooms, frying pans, dishes, etc.) and small stalls (street vendors) that were on the side of the road (both urban public roads and roads in villages) [3].

Market regulation by Surabaya Municipality was based on various reasons, namely aspects of orderliness, orderliness, cleanliness and environmental health. In addition, Surabaya Municipality 
gives full authority to the private sector in managing the market to avoid the emergence of private markets which cannot be controlled.

The basis of market regulation in Surabaya Municipality was based on several policies, including the Decree of the Governor of the Netherlands East Indies dated 23 August 1913 No.1011 / 45 concerning the regulation of market institutions by the local council [4]. Second, based on the letter of the Minister of Colonies, Idenburg on February 5, 1914, section A3 No.21 / 388 [3], and thirdly on the advice of the Council of the Netherlands Indies [6] April 14, 1914, No. XII then promulgated in the Staatsblad 1914 No. 379 about the Decentralisatie Marktwezen or decentralized market business. Based on the Governor's General Decree dated April 30, 1914, No. 3 and through the Staatsblad 1914 No. 380 market business decentralization regulations were implemented since June 1, 1914.

Giving authority to the private sector by the Surabaya Municipality in market management was based on State Gazette 1849 number 44 attachment B, articles 1 and 2. By giving part of the authority to market management to private parties, the Surabaya Municipal Government focuses more on regulating private markets that are considered threatening aspects of the order, order, cleanliness, and health. In addition, in terms of the financial economy, the emergence of erratic and mobile private markets can be financially detrimental to the Surabaya City Government because in general private markets appear erratically and generally do not pay retribution (no tax). However, the Surabaya Municipal Government did not necessarily prohibit the existence of the private market, especially the private market established on private property because this is contrary to paragraph 1 of article 60 of Government Regulation [4]. However, the municipal government could forbid the establishment of private markets on public land (both on urban roads and rural roads).

In addition, municipal governments also for reasons of order, order, health, and hygiene also limit some applications for market establishment permits. The basis for granting permission to establish a market is 1.) Municipal Regulations 2.) Dutch East Indies government regulations related to disruption (Ordinary Hinder, 1926 number 226 which was updated and supplemented by Staatsblad 1940 number 450). Hinder Ordonantie related to regulations that regulate the types of permits that were closely related to environmental pollution aspects. This ordinance was one of the regulations that directly related to environmental problems.

The colonial government divided the market into two categories, namely the wholesale market or large market or the main market, namely the market that provided goods wholesale (large parties) and domestic markets, namely markets that provided goods in retail. Large markets or wholesale markets usually provide goods for traders who will sell their goods back in retail. For this purpose, the colonial government issued a decree dated July 15, 1873 No. 37 concerning the formation of markets, especially domestic markets to reach community needs starting from urban areas to rural areas of Surabaya. Of course, the number of markets established is adjusted to the needs of the community and the regulations of the municipal government [5].

Based on Surabaya municipal government records, before the formation of the Surabaya municipality, there were 15 markets that had been established in Surabaya. The management of these markets is still in the hands of the central government (Batavia). Some of these markets were Pesapen market, Waroeng Toeri market, Misigit Gedeh market, Praban market, Baliwerti market, Kepoetran market, Pegirian market, Ampel market, Kampoeng Baroe market, Pabean market, Bong market, Kawijilan market, Peneleh market, Kali Anjar market, and Pecantian market [9]. 
Whereas the management of private markets before the arrangement by the Surabaya Municipal Government was widely owned and managed by several wealthy businessmen or government officials or retired indigenous officials. In the management of private markets, it is very difficult for market owners to control aspects of security, order, and cleanliness. Since the establishment of Surabaya as a municipality, the municipal government has gradually taken the form of taking over the existence of private markets.

Based on the Algemeen Gemeenteblad dated on June 15, 1907. It was stated that in order to strengthen the aspects of indigenous, foreign, Chinese and Arab communities, market institutions and trade support need to be established, the Surabaya municipal government needs to regulate market institutions so that conditions of security, cleanliness, order from theft, robbery and government are created. to the market and to support the financial aspects of the municipal government [6]. Based on the Algemeen Gemeenteblad, it can be said that the Surabaya Market Service was first formed in 1915.

In connection with the determination of market regulation policies, the Surabaya Municipal Government has carried out several activities such as the addition of market outlets, repairing channels, road hardening, providing insect-free lands such as flies, mosquitoes and so on, and the Ampel market that sold livestock such as goats, cows, and buffaloes.

The arrangement and arrangement of the market begin with the market arrangement of Tile, continuing on the Bong market and the Pabean market and later on the Peneleh market, Kalianyar market, Ampel market and Pegirian market in the same year, namely 1915. During the market arrangement and regulation in 1915 Surabaya gets a significant financial income.

Another important note after the establishment of the Surabaya Municipal Market Service in 1915 was market development in 1917, the Surabaya Municipal Government received 11 markets management namely the Pabean market, Genteng market, Turi market, Bong market, Peneleh market, Kali Anjar market, Ampel market, Pegirian market, Keputran market, Babaan market, and Kapasan market. In addition, since the management of the market by the municipal government there has been a significant increase in the number of buying and selling transactions, an increase in the number of traders, an increase in the number of market visitors who conduct buying and selling transactions and the decreasing number of private markets.

In the supervision of the course of market management, a market commission was formed in 1917 with its chairman Van der Spek, members of Van Dorsten and R. Priodipuro [11]. In the minutes of Gemeenteblad 1917 dated on June 22 No. 29 stated that the Market Commission had authority for local levies including markets for Surabaya municipal cash interests of $\boldsymbol{f}$ 63,081 [12]. The initial period of market regulation by the Surabaya Municipal Government had no purpose to take advantage but the government's emphasis was more on efforts to create order, security, health, and hygiene. According to the central government, all levies on market businesses were considered to be contrary to the public interest so that at the beginning of the formation of municipal market services levy charges were prohibited. However, in its development, the central government finally allowed levies to try retribution with sufficiently strict supervision to avoid corruption by municipal officials. This was based on the Dutch Indies Government Circular dated on April 17, 1925, number 727 / II [13] which was addressed to all the Municipal Councils.

Although the municipal government was permitted to collect market retributions, the central government still prohibits municipal governments from levying anything that has a tax value to markets based on Colonial Government Article 49 paragraph 2. Since being given autonomy in 
market management, the Surabaya municipal government could utilize this condition well so that the Surabaya municipal government received a substantial acceptance.

In the 1920s (until the early 1930s), the entire market began to be gradually managed by the Surabaya City Government. Starting with the takeover of the Wonokromo market, it continued with the takeover of the Sawahan market (previously owned by the OJS Company), the Kali Anjar market and the Turi market. Some private markets for health reasons were taken over by the Surabaya City Government such as the Pacar Kembang market, Krembangan market, and Kembang Kidul market.

\subsection{Market Environmental Management In Surabaya}

One of the concerns of the Surabaya Municipal Government in market exploitation activities is the aspect of the market environment. The municipal government in an effort to create order, security, cleanliness, and health of the market environment has taken several steps towards markets which are under its supervision and private markets.

In connection with market exploitation [14], the attention of the market environment was aimed at the construction of new market stalls and maintenance of existing market outlets, repair of new asphalt floors, repair of sewers, making fly-free land for meat stalls in Genteng market, in the next activity Ampel market the same was done for the sale of goat/cow/buffalo meat stalls. This activity began on 1 February 1915 for the Genteng market and Turi market. On June 1, 1915, the Customs market and Bong market. September 1, 1915, the exploitation of Peneleh market, Kali Anjar market, Ampel market, and Pegirian market. The exploitation of public markets was a source of municipal attention and the results were considered satisfactory, market acceptance in 1915.

In addition to the construction of market support facilities and infrastructure, repairs and maintenance were in the form of additional plastering, painting with white and asphalt coating on cement-coated columns, repair, replacement and lubrication of asphalt on wood, sewer repair by providing a layer of cement, gutters on paved floors, replacement of broken tiles, gratings and slats were also done. All of that was done at Pegirian market, Ampel market, Customs market, Turi market, Peneleh market, Kali Anjar market, Genteng market, Bong market, and Keputran market. In general, improving the market environment in Surabaya Municipality to meet buffet standards, comfort, cleanliness, and environmental health, the Surabaya City Government since 1915 had done the following:

a. Equity and elevation with sand on market land;

b. Making market stalls with provisions for the number of 8 market stalls with a length of 44 meters ( 2 stalls), 40 meters (two stalls), 36 meters ( 1 stall), 48 meters ( 2 stalls), and 24 meters ( 1 stall); measured at the corners of the end pillars according to the model as described in article 166 / 18b;

c. Stall stands next to the kitchen was managed like a shop for the sale of various food ingredients. Making a bathroom building with a septic tank; made entirely of cementcoated projects with stone tubs and closed with tiles, on both sides with the direction of the elongated building, which is equipped with a gutter and a corrugated drain pipe. Provision of toilets was designated by a European-only toilet, one bathroom for indigenous people. The floor was made of $7 \mathrm{~cm}$ thick concrete. Disposal of sewage was 
carried out through a concrete bus to a cement-coated septic tank, depth of 1.60 meters, covered with a concrete plate, which could then dispose of its contents in the drainage dug along 15 meters, a width of 0.50 meters and depth of 1 meter filled with sand and gravel;

d. Construction of a kitchen on the market consisting of wooden framed rooms with a tiled roof; all rely on cement-coated joints, with $7 \mathrm{~cm}$ thick concrete floors. In addition, this construction was made like a wooden market. Other parts of this building were used for washing places; other parts were used for the kitchen.

e. Making a field ahead for other horse-drawn carriage or freight stations. Fields and roads were hardened with $15 \mathrm{~cm}$ thick limestone Madurese, $8 \mathrm{~cm}$ thick gravel layer and $3 \mathrm{~cm}$ thick asphalt layer;

f. Between the market outlets, the concrete floor was made $7 \mathrm{~cm}$ sloping into the concrete gutter referred to in sub h;

g. Making a drainage tank for the market and market land, which consists of semi-circular concrete sewers, is located in the middle between the market outlets;

h. Concrete riol would drain wastewater into concrete drains and sewers on the market area, the channel was converted into concrete gutters for each market. Installation of lightweight hardener from Madura limestone and gravel;

i. Provision of market furniture includes a sales table by the municipal government.

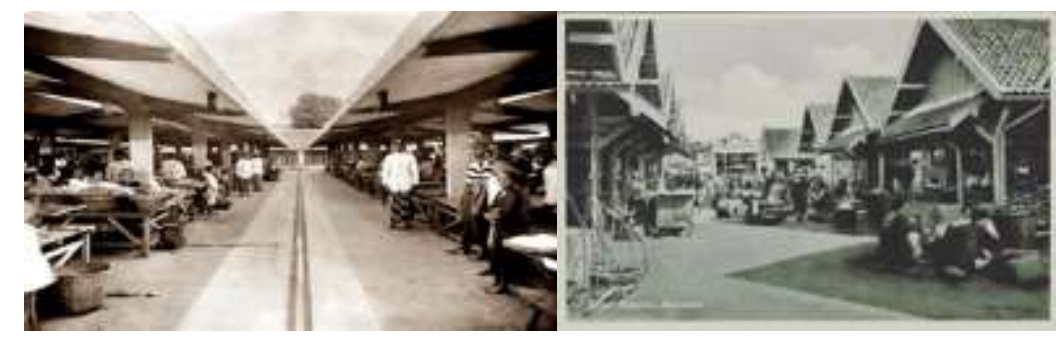

Image: Condition of Genteng Market 1920 and Kapasan Market 1930 After Renovation by Surabaya Local Government

(resource: Pinterest)

\section{Conclusions}

The existence of markets has important meaning for both the colonial government, the municipal government and for the people. The emergence of the market is based on aspects of the needs and interests of the community and government so that the colonial government, both directly and through municipal governments, needs to conduct professional management based on order, security, health, and hygiene considerations.

There were no markets throughout the Dutch East Indies that had escaped government regulation as a consequence of the importance of the market in the public interest and even the 
existence of private markets did not escape the government regulation of both the central government and the municipal government.

Since the adoption of market regulation by the government, both the central government and municipal governments have benefited from various aspects. In terms of finance, the government gets income from the levied market levies and others, namely the orderly condition of the community and the environment both from the aspect of the order, security, health, and environmental cleanliness since the government took over market management.

\section{Acknowledgements}

Acknowledgments to colleagues from the Department of Historical Education and Sociology, Faculty of Social Sciences and Law, Universitas Negeri Surabaya.

\section{References}

[1] "Decentralisatie Wet = Decentralization Law."

[2] K. M. et Al, Sejarah Statistik Ekonomi Indonesia. Jakarta: Obor Indonesia Foundation, 1987.

[3] I. G. I. J. Habbema, De Overbevolking van Java”, J.E. De Meyier\& J.H. De Bussy, Tevens Nieuwe serie van het Tijdschrift voor Nederlandsch-Indië, 4ste. Amsterdam, 1912.

[4] J. van Hasselt, Enkele Opmerkingen Betreffende het Pasarwezen. 1929.

[5] K. Tijdschrift, "Het en ander over het 'Pasar'of Marktwezen in de Gouvernementslanden op Java en Madoera", Uitgegeven door de Vereeneging van Ambtenaren bij het Binnenlandsch Bestuür in Nederlandsh Indië. 1913.

[6] G. H. Von Faber, Oud Soerabaia de Geschiedenis van Indies Eerste Koopstad van de Oudste Tijden tot de Instelling. 1931.

[3] Gemeenteblad van Soerabaja No.14 tahun 1917

[4] Gemeenteblad 1917 tanggal 22 Juni No. 29

[6] Jawa Pos, 17 November 1982

[9] Mail Rapport 23 Agustus 1913

[10] Von Faber, G.H. 1931. Oud Soerabaia de Geschiedenis van Indies Eerste Koopstad van de Oudste Tijden tot de Instelling 